\title{
Effect of dietary synbiotic on serum biochemistry and anti-oxidative function of Labeo rohita fingerlings exposed to sub-lethal nitrite stress
}

\author{
S. K. Singh ${ }^{1,2^{*}}$, V. K. Tiwari ${ }^{1}$, S. Munilkumar ${ }^{3}$, C. Prakash $^{1}$, N. K. Chadha ${ }^{1}$ and P. Biswas ${ }^{2}$
}

${ }^{1}$ Division of Aquaculture, ICAR-Central Institute of Fisheries Education, Mumbai - 400061 , Maharashtra, India; ${ }^{2}$ College of Fisheries, Central Agricultural University (Imphal), Lembucherra 799 210, Tripura, India; ${ }^{3}$ ICAR- Central Institute of Fisheries Education, Kolkata Centre, Pin- 700 091, West Bengal, India

\begin{abstract}
A 60-days feeding trial was conducted to evaluate the of supplementation of Bacillus circulans (BC) and a prebiotic fructooligosaccharide (FOS), applied alone or mixed in diet of Labeo rohita (rohu) and its effects on the serum profile [total protein, albumin (A), globulin (G), A/G ratio] and antioxidant stress enzymes [superoxide dismutase (SOD), catalase, glutathione $S$ transferase (GST)]. Fish were fed diet containing combinations of BC and FOS namely control $(0 \% \mathrm{BC}+0 \%$

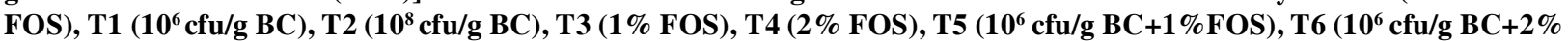
FOS $)$, T7 $\left(10^{8} \mathrm{cfu} / \mathrm{g} \mathrm{BC}+1 \%\right.$ FOS $)$ and $\mathrm{T} 8\left(10^{8} \mathrm{cfu} / \mathrm{g} \mathrm{BC}+2 \% \mathrm{FOS}\right)$. Total protein was elevated in supplemented groups, and highest observed in $\mathrm{T} 5$ group. Groups fed $\mathrm{BC}$ alone or mixed showed higher globulin levels, whereas $2 \%$ FOS lowered globulin level. A/G ratio decreased except in T4 and T8. Activity of antioxidant enzymes showed low levels in treated groups in comparision to control, with $\mathrm{T} 4$ exhibiting significantly lowest $(\mathrm{P}<0.05)$. Overall results from this study indicate the potential of using dietary BC and FOS in mixture for an improved immune function; however 2\% FOS suppressted the serum profile and digestive function of rohu juveniles.
\end{abstract}

Key words: Antioxidant, Bacillus, Prebiotic, Probitoic, Total protein

\section{Highlights}

- Synbiotic formula consisting Bacillus circulans and fructooligosaccharide (FOS) was evaluated in Labeo rohita.

- Antioxidant capacity when challenged to sub-lethal nitrite stress was improved in either, probiotic, prebiotic or synbiotic fed groups.

- Higher level of FOS at $2 \%$ impose negative impact on serum biochemical parameters and digestive enzyme activity.

- The outcome of the study throws light on positive avenue for dietary synbiotic use in aquaculture species.

\section{INTRODUCTION}

A healthy and stress-free culture environment necessitates use of immunestimulating substances. Improved growth of fishes through antibiotic application is an ageold practice and criticised because of its associated problems like resistance and residues. As a safe and effective alternative, dietary application of pro-, pre- and synbiotic in aquatic animals for an improved immune status, resulting in better growth of the fishes is revealed through a concatenation of research (Huynh et al., 2017). Applications of dietary probiotics explained as "live microorganisms which when administrated in suitable amount, deliver a health benefit for the host" (WHO/ FAO) are well documented in many fish species (Nayak, 2010). Additionally, non-digestible carbohydrates (mainly oligosaccharide) promoting beneficial growth of microbial population within the GI (gastrointestinal) tract 
of host, and referred to as prebiotic are also well established during the last decade (Ganguly et al., 2010). Prebiotic efficacy of oligosaccharides including mannan oligosaccharides (MOS), fuctooligosaccharides (FOS, or oligofructose), galactooligosaccharides, xylooligosaccharides, arabinoxylooligosaccharides and isomaltooligosaccharides is reported in aquaculture fish species (Ganguly et al., 2010). Combined application of these biotic components (synbiotic) is suggested to provide benefit of both prebiotics and probiotics towards fish growth mainly due to their synergistic effect (Cerezuela et al., 2011). So far applications of synbiotics is reported on few fish species. Despite of numerous studies examining the efficacy of probiotics and prebiotics in fish, this concept is confined to few species and regions, whereas, it is reported that synergistic effect is always not true and depends on species and dose of application (Cerezuela et al., 2011). The targeted probiotic i.e. B. circulans is previously isolated from the GI tract of $L$. rohita is found to possess extracellular protease and play a key role in the nutrition of $L$. rohita fingerlings (Ray et al., 2012). While, effect of dietary FOS used as a prebiotics has been evaluated in fishes. Research pertaining to dietary supplementation of $B$. circulans and FOS alone or coadministered in carps (to be specific L. rohita) is not tested/evaluated.

High nitrite level in culture water can exercise multitude of stress factors which can impact growth, and physiological disturbances leading to fish mortality (Lewis and Morris, 1986) and poor biomass harvest. Nitrite stress is seen commonly in many of the fish farms across the country due to unutilized feed and debris in the system. The culture intensification concomitent with higher stocking density and excessive feed and fertilizer use and increases the load of nitrogenous waste and other toxic metabolites, leading to water quality deterioration. It is also a matter of great concern for aquaculture, and necessitates immediate action (Hargreaves, 1998; Naylor et al., 2000).
The influx of nitrite into erythrocytes inevitably leads to oxidation of functional haemoglobin $\left(\mathrm{Hb}\right.$, with haem irons as $\left.\mathrm{Fe}^{2+}\right)$ to methaemoglobin, (with haem iron as $\mathrm{Fe}^{3+}$ ), which cannot bind oxygen. Earlier work from our laboratory indicates immune-enhancing role of the synbiotic, and ameorelative capacity to acidic and nitrite stress in L. rohita fingerlings (Singh et al., 2013; Singh et al., 2019). With this backdrop, the current study aimed to investigate the efficacy of a sybiotic formula, used alone or combined (synbiotic) in L. rohita upon exposure to sub-lethal nitrite stress.

\section{MATERIALS AND METHODS}

Experimental animal and maintenance: $L$. rohita fingerlings $(11.5 \pm 0.6 \mathrm{~g}$, average weight $\pm \mathrm{SE} ; \mathrm{n}=324)$ procured from commercial fish farm (Prem Fisheries Consultancy, Gujarat, India) were transported to the wet laboratory of the Central Institute of Fisheries Education, Mumbai, India. Firstly, fishes were given a prophylactic treatment through $\mathrm{KMnO}_{4}(0.15$ ppm) immersion bath to avoid disease occurrence due to transportation stress (Debbarma et al., 2021) and were then acclimatized to the laboratory conditions for 15 days prior to the experiment. They were fed $a d$ libitum using a commercial feed (30\% crude protein) obtained from Godrej Agrovet Pvt. Ltd., Andhra Pradesh, India. After the acclimation period, they were distributed randomly in nine experimental groups in triplicates (12 fish per tank) in rectangular fibre reinforced plastic tanks (water capacity $75 \mathrm{~L}$ ) following a completely randomized design (CRD). A provison for round-the-clock aeration was arranged to all the using supplied from a centralized air pump. Water quality parameters like water temperature $\left(25.0 \pm 0.1^{\circ} \mathrm{C}\right), \mathrm{pH}(6.8$ to 7.0 ), dissolved oxygen (5.8 to $6.9 \mathrm{mg} \mathrm{L}^{-1}$ ), free carbon dioxide (1.9 to $2.7 \mathrm{mg} \mathrm{L}^{-1}$ ), total hardness (156 to $\left.185 \mathrm{mg} \mathrm{L}^{-1}\right)$, ammonia-N (0.14 to $\left.0.37 \mathrm{mg} \mathrm{L}^{-1}\right)$, nitrite-N $\left(0.06 \pm 0.13 \mathrm{mg} \mathrm{L}^{-1}\right)$ and nitrate- $\mathrm{N}\left(0.03 \pm 0.14 \mathrm{mg} \mathrm{L}^{-1}\right)$ were noted at 15-days interval during the study period, and 
were found to be optimum for the growth and survival of rohu.

Culture of bacterial strain: Lyophilized B. circulans (MTCC no. 4998) used in the stusy was supplied from the Microbial Type Culture Collection and Gene Bank (MTCC), Chandigarh, India. Further, the culture was revived using a nutrient broth (Himedia, Mumbai, India) by placing in BOD incubator for $24 \mathrm{~h}$ at $30^{\circ} \mathrm{C}$. The bacteria were then cultured on nutrient agar (Himedia, Mumbai, India) and colonies were picked and sub-cultured in nutrient broth (Himedia, Mumbai, India). The isolates were confirmed as pure of $B$. circulans using a biochemical test kits (HiBacillus ${ }^{\mathrm{TM}}$ Identification Kit, Himedia). They were then mass cultured for use in the experiment. For incorporation in the diets, the culture was centrifuged at $10,000 \times g$ for $20 \mathrm{~min}$ at $4^{\circ} \mathrm{C}$. Subsequently, the pellet were washed thrice in phosphate buffer saline (PBS, pH 7.2) and resuspended in PBS, which was later quantified using spread plate technique. Then, the bacterial suspension was diluted (using PBS) in the targeted concentrations, and added to the respective test diets.

Quantification of inoculums: B. circulans was cultured on nutrient agar plates at $30^{\circ} \mathrm{C}$ for 12 $\mathrm{h}$ for determining the concentration that need to be added in the test diets. Single colony from the agar plate was aseptically inoculated and grown in $100 \mathrm{~mL}$ of nutrient broth at $30^{\circ} \mathrm{C}$ for $4 \mathrm{~h}$. Optical density (OD) was observed at 600 $\mathrm{nm}\left(\mathrm{OD}_{600}\right)$ and colony forming units (cfu) were estimated by serial dilution and spreadplate method at every $1 \mathrm{~h}$ interval. Then, the plates are incubated at $30^{\circ} \mathrm{C}$ for $12 \mathrm{~h}$ and the colonies counted. The data were subjected in graphs, to obtain relationship of the cfu versus $\mathrm{OD}_{600}$ versus time. Using this, the required microorganisms were supplied to the diets at varied concentrations.

Feed and feeding: Nine iso-caloric (1674.52 $1702.03 \mathrm{KJ} / 100 \mathrm{~g}$ ) and iso-nitrogenous (30.1 $30.6 \%$ crude protein) purified diets were formulated with different levels of the B. circulans and FOS (supplied from DPO Foods, Thane, India). The test diets used are control ( $0 \%$ BC/FOS), T1 (10 cfu/g BC), T2 (10 cfu/g BC), T3 (1\% FOS), T4 (2\% FOS), T5 $\left(10^{6} \mathrm{cfu} / \mathrm{g} \mathrm{BC}+1 \%\right.$ FOS $)$, T6 $\left(10^{6} \mathrm{cfu} / \mathrm{g} \mathrm{BC}+\right.$ $2 \% \mathrm{FOS}), \mathrm{T} 7\left(10^{8} \mathrm{cfu} / \mathrm{g} \mathrm{BC}+1 \% \mathrm{FOS}\right)$ and $\mathrm{T} 8$ $\left(10^{8} \mathrm{cfu} / \mathrm{g} \mathrm{BC}+2 \%\right.$ FOS) (described in Table 1 ). The diet was prepared using a single screw pelletizer. Ingredients were mixed thoroughly, and dough was prepared with required amount of water ( $350 \mathrm{~mL}$ of water per $\mathrm{kg}$ feed) and oil. The dough was then cooked using an autoclave (15 psi; $20 \mathrm{~min}$ ). The dought was cooled and vitamins and minerals were added. Then, FOS was dissolved in distilled water and blended with the already cooked and cooled dough. The dough was passed through a hand pelletizer to acheive an uniform size pellets of $2 \mathrm{~mm}$, air dried at room temperature $(4 \mathrm{~h})$. Then, suspended culture of $B$. circulans was sprayed over the wet extruded pellets at two concentrations $\left(10^{6}\right.$ and $\left.10^{8} \mathrm{cfu} / \mathrm{g}\right)$ and dried for $24 \mathrm{~h}$, and stored at $4^{\circ} \mathrm{C}$ until use. During storage, viable count in the feed was analyzed for 4 weeks. Fish were fed twice daily $(0900 \mathrm{~h}$ and $1700 \mathrm{~h}$ ) at a rate of $3-5 \%$ of their total biomass for 60 days. Fish were weighed every 15 days to adjust the feeding rate. Siphoning of faecal matter was done on a daily basis. Every alternate day, siphoning and water exchange was performed.

Nitrite challenge: After 60 days feeding, experimental fishes were challenged with sublethal nitrite stress $\left(1 / 5 \mathrm{LC}_{50}=2.08 \mathrm{mg} / \mathrm{L}\right)$ for 30 days. A +ve (control with stressor) $\mathrm{C}(\mathrm{P})$ and -ve (control without stressor) and a control $\mathrm{C}(\mathrm{N})$ was applied in the study to examine the antistress effect of the biotics, used alone or combined. The $96 \mathrm{hr} \mathrm{LC}_{50}$ value was calculated as $10.4 \mathrm{mg} / \mathrm{L}$. Sodium nitrite was used to reach the required nitrite levels in water.

Sampling procedure: At the trial, six fishes were collected from each treatment groups, weighed and anesthetized using clove oil (40 $\mathrm{mg} / \mathrm{L}$ ). Blood was drawn from the caudal vein 
Table 1. Formulation and composition of the experimental diets (100 $\mathrm{g}$ feed) using graded levels of Bacillus circulans and fructooligosaccharide (FOS)

\begin{tabular}{|c|c|c|c|c|c|c|c|c|c|}
\hline \multirow{2}{*}{ Ingredient } & \multicolumn{9}{|c|}{ Treatment (T) no. (B. circulans/ FOS supplementation level cfu. $\mathrm{g}^{-1} / \%$ ) } \\
\hline & $\begin{array}{l}\text { Control } \\
(\mathbf{0} / \mathbf{0})\end{array}$ & $\begin{array}{c}\text { T1 } \\
(\mathbf{0} / \mathbf{1})\end{array}$ & $\begin{array}{c}T 2 \\
(0 / 2)\end{array}$ & $\begin{array}{c}\text { T3 } \\
\left(1 \times 10^{6} / 0\right) \\
\end{array}$ & $\begin{array}{c}T 4( \\
\left.1 \times 10^{6} / 1\right)\end{array}$ & $\begin{array}{c}\text { T5 } \\
\left(1 \times 10^{6} / 2\right) \\
\end{array}$ & $\begin{array}{c}\text { T6 } \\
\left(1 \times 10^{8} / 0\right) \\
\end{array}$ & $\begin{array}{c}\text { T7 } \\
\left(1 \times 10^{8} / 1\right) \\
\end{array}$ & $\begin{array}{c}\text { T8 } \\
\left(1 \times 10^{8} / 2\right)\end{array}$ \\
\hline Casein & 42 & 42 & 42 & 42 & 42 & 42 & 42 & 42 & 42 \\
\hline Dextrin & 15 & 15 & 15 & 15 & 15 & 15 & 15 & 15 & 15 \\
\hline Cellulose & 10 & 9 & 8 & 10 & 9 & 8 & 10 & 9 & 8 \\
\hline $\begin{array}{l}\text { Starch } \\
\text { soluble }\end{array}$ & 10 & 10 & 10 & 10 & 10 & 10 & 10 & 10 & 10 \\
\hline Gelatin & 8 & 8 & 8 & 8 & 8 & 8 & 8 & 8 & 8 \\
\hline $\begin{array}{l}\text { Cod liver } \\
\text { oil }\end{array}$ & 5 & 5 & 5 & 5 & 5 & 5 & 5 & 5 & 5 \\
\hline $\begin{array}{l}\text { Sunflower } \\
\text { oil }\end{array}$ & 3 & 3 & 3 & 3 & 3 & 3 & 3 & 3 & 3 \\
\hline $\mathrm{CMC}$ & 2 & 2 & 2 & 2 & 2 & 2 & 2 & 2 & 2 \\
\hline $\begin{array}{l}\text { Mineral } \\
\text { Premix }\end{array}$ & 2 & 2 & 2 & 2 & 2 & 2 & 2 & 2 & 2 \\
\hline $\begin{array}{l}\text { Vitamin } \\
\text { Premix b }\end{array}$ & 2 & 2 & 2 & 2 & 2 & 2 & 2 & 2 & 2 \\
\hline $\mathrm{BHC}$ & 1 & 1 & 1 & 1 & 1 & 1 & 1 & 1 & 1 \\
\hline Prebiotic & 0.00 & 1.00 & 2.00 & 0.00 & 1.00 & 2.00 & 0.00 & 1.00 & 2.00 \\
\hline Probiotic & 0.00 & 0.00 & 0.00 & $1 \times 10^{6}$ & $1 \times 10^{6}$ & $1 \times 10^{6}$ & $1 \times 10^{8}$ & $1 \times 10^{8}$ & $1 \times 10^{8}$ \\
\hline BHT & 0.01 & 0.01 & 0.01 & 0.01 & 0.01 & 0.01 & 0.01 & 0.01 & 0.01 \\
\hline
\end{tabular}

a - Mineral premix (\%): KAl(SO4)2, 0.159; $\mathrm{CaCO} 3,18.101 ; 0.07$; KCl, 16.553; 1.338; MnSO4.H2O, 0.07; KI, 0.014; ZnSO4, 0.192; NaH2PO4, 13.605; CuSO4.5H2O, 0.075;

b - Vitamin premix: thiamine hydrochloride, $10 \mathrm{mg} \mathrm{kg}$-1; riboflavin, $20 \mathrm{mg} \mathrm{kg}-1$; calcium pantothenate, $40 \mathrm{mg} \mathrm{kg}-1$; nicotinic acid, $50 \mathrm{mg} \mathrm{kg-1}$; pyridoxine hydrochloride, $10 \mathrm{mg} \mathrm{kg}-1$; folic acid, $5 \mathrm{mg} \mathrm{kg}-1$; inositol, $400 \mathrm{mg} \mathrm{kg}-1$; choline chloride, $2000 \mathrm{mg} \mathrm{kg-1}$; menadione, $10 \mathrm{mg} \mathrm{kg-1;} \mathrm{cholecalciferol,} 1500 \mathrm{IU}$; biotin, $1 \mathrm{mg} \mathrm{kg}-1$; vitamin B12, $0.02 \mathrm{mg} \mathrm{kg}-1$; vitamin A, $3000 \mathrm{IU}$; vitamin E, $50 \mathrm{IU}$; vitamin C, $200 \mathrm{mg} \mathrm{kg}-1$; *DE= Digestible energy

by a $1 \mathrm{~mL}$ medical syringe ( $28 \mathrm{~mm}$ needles), previously coated with a $2.7 \%$ EDTA solution. For serum assays, blood was drawn in eppendorf tubes (no anticoagulant), which was allowed to clot for another $2 \mathrm{~h}$ at $4{ }^{\circ} \mathrm{C}$, and centrifuged at $3000 \times \mathrm{g}$ for $15 \mathrm{~min}$. The supernatant was pooled and stored at $-20^{\circ} \mathrm{C}$ for future use. Serum protein was estimated following Biuret and BCG dye binding method (Reinhold, 1953) using commercial kit (total protein and albumin kit; Qualigens Diagnostics). Albumin was quantified by bromo-cresol green binding method (Doumas et al., 1971). The absorbance were measured comparing a blank using spectrophotometer $(630 \mathrm{~nm})$. Globulin value was calculated as total protein minus albumin values. A/G ratio was obtained as albumin divided by globulin. Catalase activity was quantified as per Takahara et al. (1960). The SOD activity was quantified following Misra and Fridovich (1972). Glutathione-s-transferase (GST) activity was estimated by the method of Habing et al. (1974).

Statistical analysis: Generated data were analyzed using statistical package, Statistical Package for the Social Sciences (SPSS, version 16) applying one way and two-way Analysis 
of Variance (ANOVA), and Duncan's Multiple Range (DMR) tests to see the significant differences between the means. Comparisons were made at the $5 \%$ probability level. Results are represented as mean \pm standard error $(\mathrm{SE})$.

\section{RESULTS}

Serum biochemistry: Pre- and post challenge serum total protein upon sub-lethal nitrite exposure is given in Table 2. Serum total protein post challenge decreased and showed significance in groups $\mathrm{C}(\mathrm{P}) \& \mathrm{~T} 2$. Pre- and post challenge value was highest in T4 (54.34 \pm 0.82 ; $52.18 \pm 0.48)$ and lowest in $\mathrm{C}(\mathrm{P})(46.37 \pm 0.54$; $39.82 \pm 0.40)$. B. circulans supplementation had significant $(P<0.05)$ effect on serum total protein, whereas, FOS did not. Interaction between them was also non-significant. Pre- and

Table 2. Serum biochemical profile of pre and post challenge immune enhanced $L$. rohita after subsequent exposure to sub-lethal nitrite stress

\begin{tabular}{|c|c|c|c|c|c|c|c|c|}
\hline \multirow[t]{2}{*}{ Treatments } & \multicolumn{2}{|c|}{$\begin{array}{l}\text { Total protein } \\
(\mathrm{g} / \mathrm{L})\end{array}$} & \multicolumn{2}{|c|}{$\begin{array}{c}\text { Albumin } \\
(\mathrm{g} / \mathrm{L})\end{array}$} & \multicolumn{2}{|c|}{$\begin{array}{c}\text { Globulin } \\
(\mathrm{g} / \mathrm{L})\end{array}$} & \multicolumn{2}{|c|}{ A/G ratio } \\
\hline & Pre & Post & Pre & Post & Pre & Post & Pre & Post \\
\hline \multirow[t]{2}{*}{$\mathrm{C}(\mathrm{N})$} & $46.39^{\mathrm{ab}}$ & $47.83^{b}$ & 6.28 & 6.33 & $35.17^{\mathrm{b}}$ & $36.83^{b}$ & $0.175^{\mathrm{a}}$ & $0.168^{\mathrm{b}}$ \\
\hline & \pm 0.28 & \pm 0.61 & \pm 0.93 & \pm 0.48 & \pm 3.28 & \pm 5.28 & \pm 0.00 & \pm 0.00 \\
\hline \multirow[t]{2}{*}{$\mathrm{C}(\mathrm{P})$} & $46.37^{\mathrm{abB}}$ & $39.82^{\mathrm{aA}}$ & 6.34 & 6.41 & $35.56^{\mathrm{abB}}$ & $32.16^{\mathrm{aA}}$ & $0.176^{\mathrm{aA}}$ & $0.199^{\mathrm{aB}}$ \\
\hline & \pm 0.54 & \pm 0.40 & \pm 1.01 & \pm 0.76 & \pm 2.45 & \pm 4.34 & \pm 0.00 & \pm 0.00 \\
\hline \multirow[t]{2}{*}{$\mathrm{T} 1$} & $49.39^{\mathrm{b}}$ & $46.78^{b}$ & 6.28 & 6.36 & $38.59^{\mathrm{b}}$ & $36.87^{\mathrm{b}}$ & $0.163^{\mathrm{b}}$ & $0.172^{\mathrm{b}}$ \\
\hline & \pm 0.63 & \pm 0.52 & \pm 1.06 & \pm 0.89 & \pm 4.38 & \pm 5.26 & \pm 0.00 & \pm 0.00 \\
\hline \multirow[t]{2}{*}{$\mathrm{T} 2$} & $45.48^{\mathrm{abB}}$ & $38.63^{\mathrm{aA}}$ & 6.37 & 6.47 & $36.12^{\mathrm{abB}}$ & $32.04^{\mathrm{aA}}$ & $0.176^{\mathrm{aA}}$ & $0.201^{\mathrm{abB}}$ \\
\hline & \pm 0.39 & \pm 0.69 & \pm 0.94 & \pm 0.53 & \pm 4.18 & \pm 1.94 & \pm 0.00 & \pm 0.00 \\
\hline \multirow[t]{2}{*}{$\mathrm{T} 3$} & $53.36^{c}$ & $50.56^{c}$ & 6.12 & 6.29 & $40.32^{\mathrm{b}}$ & $37.48^{\mathrm{b}}$ & $0.151^{b c}$ & $0.167^{\mathrm{b}}$ \\
\hline & \pm 0.78 & \pm 0.62 & \pm 0.86 & \pm 1.04 & \pm 5.39 & \pm 4.22 & \pm 0.00 & \pm 0.00 \\
\hline \multirow[t]{2}{*}{$\mathrm{T} 4$} & $54.34^{\mathrm{c}}$ & $52.18^{\mathrm{d}}$ & 6.21 & 6.28 & $41.87^{\mathrm{b}}$ & $39.29^{c}$ & $0.148^{\mathrm{c}}$ & $0.159^{b}$ \\
\hline & \pm 0.82 & \pm 0.48 & \pm 0.68 & \pm 1.03 & \pm 6.26 & \pm 3.75 & \pm 0.00 & \pm 0.00 \\
\hline \multirow[t]{2}{*}{ T5 } & $52.16^{\mathrm{bc}}$ & $50.37^{\mathrm{c}}$ & 6.18 & 6.26 & $41.12^{\mathrm{b}}$ & $38.94^{\mathrm{bc}}$ & $0.150^{\mathrm{bc}}$ & $0.160^{\mathrm{b}}$ \\
\hline & \pm 0.59 & \pm 0.51 & \pm 0.73 & \pm 0.98 & \pm 5.77 & \pm 4.29 & \pm 0.00 & \pm 0.00 \\
\hline \multirow[t]{2}{*}{ T6 } & $51.87^{\mathrm{bc}}$ & $48.58^{\mathrm{b}}$ & 6.22 & 6.31 & $40.86^{b}$ & $38.07^{\mathrm{bc}}$ & $0.152^{\mathrm{bc}}$ & $0.165^{\mathrm{b}}$ \\
\hline & \pm 0.77 & \pm 0.55 & \pm 1.26 & \pm 1.12 & \pm 3.29 & \pm 3.74 & \pm 0.00 & \pm 0.00 \\
\hline \multirow[t]{2}{*}{$\mathrm{T} 7$} & $51.62^{\mathrm{bc}}$ & $48.21^{\mathrm{b}}$ & 6.19 & 6.30 & $40.52^{\mathrm{b}}$ & 37.79 & $0.153^{b c}$ & $0.166^{\mathrm{b}}$ \\
\hline & \pm 0.52 & \pm 0.79 & \pm 0.88 & \pm 0.64 & \pm 2.89 & $\pm 4.12^{\mathrm{bc}}$ & \pm 0.01 & \pm 0.00 \\
\hline \multirow[t]{2}{*}{$\mathrm{T} 8$} & $50.37^{\mathrm{bc}}$ & $47.97^{\mathrm{b}}$ & 6.23 & 6.27 & $40.11^{\mathrm{b}}$ & $38.77^{\mathrm{bc}}$ & $0.155^{\mathrm{bc}}$ & $0.161^{\mathrm{b}}$ \\
\hline & \pm 0.66 & \pm 0.48 & \pm 0.90 & \pm 0.86 & \pm 3.64 & \pm 3.28 & \pm 0.00 & \pm 0.00 \\
\hline \multicolumn{9}{|c|}{ Two way ANOVA } \\
\hline $\mathrm{P}(\mathrm{BC})$ & 0.000 & 0.000 & 0.074 & 0.091 & 0.000 & 0.001 & 0.001 & 0.000 \\
\hline $\mathrm{P}(\mathrm{FOS})$ & 0.061 & 0.052 & 0.063 & 0.182 & 0.126 & 0.066 & 0.082 & 0.072 \\
\hline $\begin{array}{c}\mathrm{P} \\
\text { (Interactions) }\end{array}$ & 0.375 & 0.627 & 0.119 & 0.729 & 0.538 & 0.034 & 0.113 & 0.159 \\
\hline
\end{tabular}

Data expressed as mean \pm SE, Mean values $(n=3)$ in a column under each category bearing different superscript (lower case) vary significantly $(\mathrm{P}<0.05)$. Mean values $(\mathrm{n}=3)$ in a row under each parameter bearing different superscript (capital) vary significantly $(\mathrm{P}<0.05)$ 
post challenge serum albumin after sub-lethal nitrite stress exposure is given in Table 2. Serum albumin after challenge increased in all groups, and was significant in $\mathrm{C}(\mathrm{P})$ \& $\mathrm{T} 2$. Post challenge albumin level was highest in $\mathrm{T} 2$ $(6.47 \pm 0.53)$ and lowest in T8 (6.27 \pm 0.86$)$. There was no significant $(\mathrm{P}>0.05)$ effect of $B$. circulans and FOS supplementation on serum albumin. Serum globulin pre and post challenge with sub-lethal nitrite stress is given in Table 2. Serum globulin decreased post challenge with sub-lethal nitrite stress and was significant in C (P) \& T2. Pre challenge value was highest in T4 $(41.87 \pm 6.26)$ and lowest in $\mathrm{C}(\mathrm{N})$ $(35.17 \pm 3.28)$ whereas post challenge was value was highest in T4 $(39.29 \pm 3.75)$ and lowest in C (P) $(32.16 \pm 4.34)$. B. circulans had significant individual effect whereas FOS did not exert significant effect on pre and post serum globulin level. Interaction between B. circulans and FOS was significant only in post challenge serum globulin level. Serum A/G ratio increased following exposure and was significant in $\mathrm{C}(\mathrm{P})$ and $\mathrm{T} 2$ groups. Pre challenge ratio was highest in $\mathrm{C}(\mathrm{P}) \& \mathrm{~T} 2(0.176 \pm 0.00)$ and lowest in $\mathrm{T} 4$ $(0.148 \pm 0.00)$. Post challenge ratio was highest in $\mathrm{C}(\mathrm{P})(0.199 \pm 0.00)$ and lowest in $\mathrm{T} 4$ $(0.159 \pm 0.00)$. B. circulans had significant individual effect whereas FOS did not exert significant effect on pre and post serum A/G ratio.

Antioxidant enzymes: The anti-oxidative enzymes viz. superoxide dismutase (SOD), catalase, glutathione $S$ transferase (GST) activity in different tissues of immune enhanced L. rohita fingerlings after exposure to 30 days sub-lethal nitrite stress are given in Table 3. SOD activity in gill and liver tissue was lowest in T4 $(26.64 \pm 0.82 ; 27.52 \pm 0.41)$ and highest in $\mathrm{C}(\mathrm{P})$ $(42.96 \pm 0.93 ; 44.79 \pm 0.80)$. Both $B$. circulans and FOS exerted significant $(\mathrm{P}<0.05)$ individual effect on SOD activity in gill and liver; however no significant interaction occurred between them. Catalase activity in gill and liver tissue was highest in $\mathrm{C}(\mathrm{P})(1.64 \pm 0.01 ; 2.23 \pm 0.04)$ and lowest in T4 $(1.33 \pm 0.01 ; 1.43 \pm 0.00)$. Both $B$. circulans and FOS exerted significant $(\mathrm{P}<0.05)$ individual effect on SOD activity in gill and liver; however no significant interaction occurred between them. In gill tissue, GST activity was highest in $\mathrm{C}(\mathrm{P})(0.52 \pm 0.01)$ and lowest in $\mathrm{T} 4(0.34 \pm 0.01)$ whereas in liver the activity was highest in $\mathrm{T} 2(0.47 \pm 0.03)$ and lowest in T4 $(0.33 \pm 0.01)$. B. circulans exhibited significant $(\mathrm{P}<0.05)$ individual effect on gill GST activity whereas FOS did not. No significant interaction occurred between them. $B$. circulans and FOS exhibited significant $(\mathrm{P}<0.05)$ individual effect on liver GST activity.

\section{DISCUSSION}

Serological parameters viz. total protein, albumin, globulin and $\mathrm{A} / \mathrm{G}$ ratio in this study was better in both probiotic and prebiotic supplemented groups. Earlier probiotics and prebiotics are known to enhance immune status of fishes indicated by enhanced serum parameters (Wang et al., 2021). In this study, only probiotic $B$. circulans exhibited individual effect on serum parameters suggesting its possible role in ameliorating nitrite induced stress in L. rohita. Further no significant interaction occurred between $B$. circulans and FOS and the better serological parameters observed in combination feeding may be a sole contribution from probiotics. However, in contrast to this finding, Sang et al. (2009) reported higher immune response of marrion (Cherax tenuimanus) after feeding dietary MOS. He also reported that fishes after challenge with $\mathrm{NH}_{3}$ stress was able to withstand stress due to immune enhancement. The SOD activity increased post sub-lethal nitrite stress challenge in this study and this is to prevent the natural oxidation of epinephrine, the concentration of which is generally increased in stressed fish. This result confirms the protective role of this enzyme against acidic induced stressors. SOD activity was lower in the treated group compared to control. Fishes fed combination of $B$. circulans and FOS exhibited lower level than either fed individually or deprived of these supplements. 
Table 3. Antioxidant enzyme activity of immune enhanced Labeo rohita after subsequent exposure to sub-lethal nitrite stress

\begin{tabular}{|c|c|c|c|c|c|c|}
\hline \multirow[t]{2}{*}{ Treatments } & \multicolumn{2}{|c|}{$\begin{array}{c}\text { SOD } \\
\text { (Units/mg protein/min) }\end{array}$} & \multicolumn{2}{|c|}{$\begin{array}{c}\text { Catalase } \\
\text { (Units/mg protein/min) }\end{array}$} & \multicolumn{2}{|c|}{$\begin{array}{c}\text { GST } \\
\text { (Units/mg protein/min) }\end{array}$} \\
\hline & Gill & Liver & Gill & Liver & Gill & Liver \\
\hline \multirow[t]{2}{*}{$\mathrm{C}(\mathrm{N})$} & $27.01^{\mathrm{ab}}$ & $30.31^{\mathrm{b}}$ & $1.35^{\mathrm{ab}}$ & $1.56^{\mathrm{b}}$ & $0.45^{b}$ & $0.36^{\mathrm{ab}}$ \\
\hline & \pm 0.32 & \pm 0.55 & \pm 0.01 & \pm 0.01 & \pm 0.01 & \pm 0.00 \\
\hline \multirow[t]{2}{*}{$\mathbf{C}(\mathbf{P})$} & $42.96^{\mathrm{f}}$ & $44.79^{\mathrm{d}}$ & 1.64 & $2.23^{\mathrm{d}}$ & $0.52^{\mathrm{c}}$ & $0.46^{\mathrm{c}}$ \\
\hline & \pm 0.93 & \pm 0.80 & $\pm 0.01^{\mathrm{f}}$ & \pm 0.04 & \pm 0.01 & \pm 0.01 \\
\hline \multirow[t]{2}{*}{ T1 } & $29.63^{\mathrm{bcd}}$ & $31.31^{\mathrm{b}}$ & 1.39 & $1.60^{\mathrm{bc}}$ & $0.46^{\mathrm{b}}$ & $0.38^{\mathrm{ab}}$ \\
\hline & \pm 0.61 & \pm 0.49 & $\pm 0.01^{\text {cde }}$ & \pm 0.02 & \pm 0.01 & \pm 0.01 \\
\hline \multirow[t]{2}{*}{$\mathbf{T 2}$} & $32.61^{\mathrm{e}}$ & $34.88^{\mathrm{c}}$ & $1.43^{\mathrm{e}}$ & $1.66^{\mathrm{c}}$ & $0.51^{\mathrm{c}}$ & $0.47^{\mathrm{c}}$ \\
\hline & \pm 0.71 & \pm 0.77 & \pm 0.01 & \pm 0.01 & \pm 0.01 & \pm 0.03 \\
\hline \multirow[t]{2}{*}{ T3 } & $28.48^{\mathrm{abcd}}$ & $29.48^{\mathrm{ab}}$ & $1.38^{\mathrm{bc}}$ & $1.48^{\mathrm{a}}$ & $0.43^{\mathrm{b}}$ & $0.37^{\mathrm{ab}}$ \\
\hline & \pm 0.69 & \pm 0.42 & \pm 0.01 & \pm 0.02 & \pm 0.01 & \pm 0.01 \\
\hline \multirow[t]{2}{*}{ T4 } & $26.64^{\mathrm{a}}$ & $27.52^{\mathrm{a}}$ & $1.33^{\mathrm{a}}$ & $1.43^{\mathrm{a}}$ & $0.34^{\mathrm{a}}$ & $0.33^{\mathrm{a}}$ \\
\hline & \pm 0.82 & \pm 0.41 & \pm 0.01 & \pm 0.00 & \pm 0.01 & \pm 0.01 \\
\hline \multirow[t]{2}{*}{ T5 } & $28.09^{a b c}$ & $30.19^{\mathrm{b}}$ & $1.34^{\mathrm{ab}}$ & $1.46^{\mathrm{a}}$ & $0.36^{\mathrm{a}}$ & $0.37^{\mathrm{ab}}$ \\
\hline & \pm 0.71 & \pm 0.69 & \pm 0.01 & \pm 0.01 & \pm 0.01 & \pm 0.01 \\
\hline \multirow[t]{2}{*}{ T6 } & $27.80^{\mathrm{abc}}$ & $30.11^{\mathrm{b}}$ & $1.39^{\mathrm{cd}}$ & $1.60^{\mathrm{bc}}$ & $0.43^{\mathrm{b}}$ & $0.38^{\mathrm{ab}}$ \\
\hline & \pm 0.90 & \pm 1.17 & \pm 0.01 & \pm 0.02 & \pm 0.01 & \pm 0.02 \\
\hline \multirow[t]{2}{*}{ T7 } & $30.08^{\text {cde }}$ & $31.25^{\mathrm{b}}$ & $1.41^{\text {cde }}$ & $1.58^{\mathrm{b}}$ & $0.38^{a}$ & $0.37^{\mathrm{ab}}$ \\
\hline & \pm 1.23 & \pm 1.11 & \pm 0.01 & \pm 0.02 & \pm 0.01 & \pm 0.02 \\
\hline \multirow[t]{2}{*}{ T8 } & $30.93^{\mathrm{de}}$ & $33.74^{\mathrm{c}}$ & $1.42^{\mathrm{de}}$ & $1.56^{\mathrm{b}}$ & $0.36^{\mathrm{a}}$ & $0.40^{\mathrm{b}}$ \\
\hline & \pm 0.98 & \pm 0.75 & \pm 0.01 & \pm 0.01 & \pm 0.01 & \pm 0.02 \\
\hline $\mathbf{P}(\mathbf{B C})$ & 0.000 & 0.001 & 0.001 & 0.000 & 0.010 & 0.00 \\
\hline P (FOS) & 0.028 & 0.046 & 0.029 & 0.039 & 0.081 & 0.027 \\
\hline $\begin{array}{c}\mathbf{P} \\
\text { (Interactions) }\end{array}$ & 0.167 & 0.255 & 0.218 & 0.485 & 0.225 & 0.172 \\
\hline
\end{tabular}

Data expressed as mean \pm SE, Mean values $(n=3)$ in a column under each category bearing different superscript (lower case) vary significantly $(\mathrm{P}<0.05)$

However, no synergistic effect was seen due to combination feeding. No literature is available in support of our finding. Similarly, catalase activity was lower in groups fed combination of these two biotics than fed singly indicating protective role against environmental acid induced stressors due to dietary supplementation. Catalase activity usually elevates upon exposure to xenobiotics or biological pathogens. The target function of catalase is to protect the cells from the accumulation of $\mathrm{H}_{2} \mathrm{O}_{2}$ by dismuting it to form $\mathrm{H}_{2} \mathrm{O}$ and $\mathrm{O}_{2}$ or by using it as an oxidant where it works as a peroxidase. Probiotics may enhance phagocytic activity and increase the production of ROS (reactive oxygen species) by macrophages, which follows an increased stimulation of its activity (Panigrahi et al., 2005). Glutathione-S-transferase (GST) is an abundant cytosolic antioxidant involved in conjugation of toxic reactive metabolites. The higher tripeptide content is involved in the activation of $\gamma$-glutamylcysteine synthetase, one of the enzymes involved in glutathione synthesis (Ding et al., 2000). GST activity was lower in treatment groups compared to positive control. Activity was lowest in groups fed combination doses (T4) indicating better 
condition of fish under stressful environment.

Overall outcome of this study indicates that both probiotic $B$. circulans and prebiotic FOS used as dietary supplements posses immunomodulatory effect and has the capacity to provide protection to Labeo rohita fingerlings against sub-lethal nitrite stress.

Conflict of interest: Authors have no conflict of interest in this study.

Author's contribution: SKS: Involved in experimental design, methodology, draft preparation; VKT: Involved in conceptualization,

\section{REFERENCES}

Cerezuela R, Meseguer J and Esteban A, 2011. Current knowledge in symbiotic use for fish aquaculture: A review. J Aquacul Res Dev, doi: 10.4172/21559546.S1-008

Ding WX, Shen HM and Ong CN, 2000. Microcystic cyanobacteria extract induces cytoskeletal disruption and intracellular glutathione alteration in hepatocytes. Environ Health Perspect, 108: 605-609, doi: 10.1289/ehp.00108605

Doumas BT, Watson W and Biggs HG, 1971. Albumin standards and measurement of serum albumin with bromocresol green. Clin Chim Acta, 31: 8796, doi: 10.1016/0009-8981(71)90365-2

Ganguly S, Paul I and Mukhopadhayay SK, 2010. Application and effectiveness of immunostimulants, probiotics, and prebiotics in aquaculture: A Review. Israeli J Aquacult Bamidgeh, 62(3): 130-138

Habing WH, Pabst MN and Jacoby WB, 1974. Glutathione S-transferases. Transferase, the first enzymatic step in mercatpopunc acid formation. J Biol Chem, 249: 7130-7138

Hargreaves JA, 1998. Nitrogen bio-geochemistry of aquaculture ponds. Aquaculture, 166: 181-212, doi: 10.1016/S0044-8486(98)00298-1

Huynh TG, Shiu YL, Nguyen TP, Truong QP, Chen JC et al., 2017. Current applications, selection, and possible mechanisms of actions of synbiotics in improving the growth and health status in aquaculture: A review. Fish Shellfish Immunol, 64: 367-382, doi: 10.1016/j.fsi.2017.03.035

Lewis JWM and Morris DP, 1986. Toxicity of nitrite data curation and revision of draft; SM: Involved for data analysis and revision; CP: Involved in data curation, methods; NKC: Involved in laboratory facilities; PB: Involved in proof reading.

\section{ACKNOWLEDGEMENT}

The authors acknowledge Indian Council of Agricultural Research, New Delhi, India for the financial support. Due thanks is extended to the Director, ICAR-Central Institute of Fisheries Education, Mumbai, India for the facilities and support during the study period.

to fish: A review. Trans Am Fish Soc, 115: 183195, doi: 10.1577/1548-8659(1986)115<183: TONTF $>2.0 . \mathrm{CO} ; 2$

Misra HP and Fridovich I, 1972. The role of superoxide anion in the autoxidation of epinephrine and a simple assay for superoxide dismutase, J Biol Chem, 247: 3170-3175

Nayak SK, 2010. Probiotics and immunity: A fish perspective, Fish Shellfish Immunol, 29: 2-14, doi: 10.1016/j.fsi.2010.02.017

Naylor RL, Goldburg RJ and Primavera JH, Kautsky $\mathrm{N}$, Beveridge MC et al., 2000. Effect of aquaculture on world fish supplies. Nature, 405: 1017-1024, doi: 10.1038/35016500

Panigrahi A, Kiron V, Puangkaew J, Kobayashi T, Satoh S et al., 2005. The viability of probiotic as a factor influencing the immune response in rainbow trout Oncorhynchus mykis. Aquaculture, 243: 241-254, doi: 10.1016/j.aquaculture.2004.09.032

Ray AK, Ghosh K and Ring $\varnothing$ E, 2012. Enzymeproducing bacteria isolated from fish gut: A review. Aquacult Nutr, 18: 465-492, doi: 10.1111/ j.1365-2095.2012.00943.x

Reinhold JG, 1953. Manual determination of serum total protein, albumin and globulin fractions by Biuret method. In: Standard Method of Clinical Chemistry (ed. by M. Reiner), Academic Press, New York, NY, USA, pp 88

Sang HM, Ky LT and Fotedar R, 2009. Dietary supplementation of mannan oligosaccharide improves the immune responses and survival of marron, Cherax tenuimanus (Smith, 1912) when 


\section{Dietary synbiotic application in rohu against nitrite stress}

challenged with different stressors. Fish Shellfish Immunol, 27: 341-348, doi: 10.1016/ j.fsi.2009.06.003

Singh SK, Tiwari VK, Chadha NK, Prakash C, Munilkumar S et al., 2013. Effect of Bacillus circulans and fructooligosaccharide supplementation on growth and haematoimmunological function of Labeo rohita (Hamilton, 1822) fingerlings exposed to sublethal nitrite stress, Israeli J Aquacult Bamidgeh, 67, doi: 10.46989/001c.20673

Singh SK, Tiwari VK, Chadha NK, Munilkumar S, Prakash C et al., 2019. Effect of dietary synbiotic supplementation on growth, immune and physiological status of Labeo rohita juveniles exposed to low $\mathrm{pH}$ stress. Fish Shellfish Immunol, 91: 358-368, doi: 10.1016/j.fsi.2019.05.023

Takahara S, Hamilton BH, Nell JV, Kobra TY, Ogura Y et al., 1960. Hypocatalesemia, A new generis carrier state. J Clin Invest, 29: 610-619, doi: 10.1172/JCI104075

Wang T, Zhang N, Yu XB, Qiao F, Chen LQ et al., 2021. Inulin alleviates adverse metabolic syndrome and regulates intestinal microbiota composition in Nile Tilapia (Oreochromis niloticus) fed with high-carbohydrate diet. Br J Nutr, 126: 161-171, doi: 10.1017/S00071145 2000402X

Received - 02.10.2021, Accepted - 14.11.2021, Published-01.12.2021

Section Editor: Prof. S. K. Das, Member, Editorial Board 